University of Nebraska - Lincoln DigitalCommons@University of Nebraska - Lincoln

Faculty Publications: Political Science

Political Science, Department of

2018

\title{
Genetic Attributions: Sign of Intolerance or Acceptance?
}

Stephen P. Schneider

Kevin B. Smith

John R. Hibbing

Follow this and additional works at: http://digitalcommons.unl.edu/poliscifacpub

Part of the Political Science Commons

This Article is brought to you for free and open access by the Political Science, Department of at DigitalCommons@University of Nebraska - Lincoln. It has been accepted for inclusion in Faculty Publications: Political Science by an authorized administrator of DigitalCommons@University of Nebraska Lincoln. 


\title{
Genetic Attributions: Sign of Intolerance or Acceptance?
}

\author{
Stephen P. Schneider, University of Nebraska-Lincoln \\ Kevin B. Smith, University of Nebraska-Lincoln \\ John R. Hibbing, University of Nebraska-Lincoln
}

\begin{abstract}
Many scholars argue that people who attribute human characteristics to genetic causes also tend to hold politically and socially problematic attitudes. More specifically, public acceptance of genetic influences is believed to be associated with intolerance, prejudice, and the legitimation of social inequities and laissez-faire policies. We test these expectations with original data from two nationally representative samples that allow us to identify the American public's attributional patterns across 18 diverse traits. Key findings are (1) genetic attributions are actually more likely to be made by liberals, not conservatives; (2) genetic attributions are associated with higher, not lower, levels of tolerance of vulnerable individuals; and (3) genetic attributions do not correlate with unseemly racial attitudes.
\end{abstract}

W hy do people believe that individuals are the way they are? This is an important question because the presumed causes of personal traits and behaviors are known to have a significant influence on the public attitudes and policies directed at individuals displaying those traits and behaviors (Haider-Markel and Joslyn 2008). To fully understand the attitudes and policies on issues as diverse as obesity, drug addiction, and sexual orientation is impossible without understanding what the public believes causes those traits. Despite this importance, current understanding of such causal attributions and their political implications is muddled.

A long-held, central assertion of academic theorizing on the topic is that people who attribute human characteristics to genetic causes are more likely to be conservative, intolerant, and racist (e.g., Gould 1996; Lewontin, Rose, and Kamin 1984). The basic logic follows essentialism: if traits are seen as unchangeable and map onto existing social differences, inequalities, and hierarchies, then these differences, inequalities, and hierarchies are likely to be viewed as part of a natural order that government policy should not and cannot change (Heine et al. 2017). Yet for at least one highly salient trait — sexual orientation - genetic attribution is clearly correlated with more liberal and tolerant attitudes (Haider-Markel and Joslyn 2008; Joslyn and Haider-Markel 2016; Suhay and Jayaratne 2013). The "born that way" perspective argues that acceptance of diverse sexual orientations is enhanced by recognizing the deep biological bases of those orientations.

Three factors have prevented empirical investigations from reconciling these opposing views. First, most previous studies examine only a small number of traits, making it difficult to draw broader conclusions. Second, previously employed survey probes tend to lack precision, asking respondents only to assess the importance of genetics to variation in a given trait even as people undoubtedly have vastly different thresholds for what counts as "important" (Shostak et al. 2009). Third, available survey items often lump all nongenetic causes together (e.g., Shostak et al. 2009), even though personal choice and environmental sources are quite different. Survey respondents need a fuller range of options for a couple of reasons. First, when given the option, the lay public ascribes substantial influence specifically to human agency

Stephen P. Schneider (stphnschndr@huskers.unl.edu) is a PhD candidate, Kevin B. Smith (ksmith1@unl.edu) is a professor of political science, and John R. Hibbing (jhibbing1@unl.edu) is a Foundation Regents Professor of Political Science at the University of Nebraska-Lincoln, Lincoln, NE 68588.

Data and supporting materials necessary to reproduce the numerical results in the article are available in the JOP Dataverse (https://dataverse.harvard.edu /dataverse/jop). An online appendix with supplementary material is available at http://dx.doi.org/10.1086/696860.

The Journal of Politics, volume 80, number 3. Published online May 10, 2018. http://dx.doi.org/10.1086/696860

(c) 2018 by the Southern Political Science Association. All rights reserved. 0022-3816/2018/8003-0021\$10.00 
(Condit et al. 2006). In contrast, behavioral genetics methodologies typically do not recognize or estimate personal choice (personal choice, if real, would be present in the error term of these estimation techniques, but there would be no way to distinguish its influence from measurement error). Second, the key theoretical construct distinguishing among causes appears to be the presumed ability of the individual to control his or her behavior (on controllability, see Weiner 1985). Genetics is perceived by the public as largely beyond the control of individuals (although recent discoveries on epigenetics raise doubts about this), while the environment contains both uncontrollable (exposure to chemicals while in the womb) and controllable (avoiding walking right past the bar) elements. In addition to genetics and the environment, we thus include a third, distinct attributional category that is clearly controllable, and we refer to it as personal choice.

In order to improve previous instrumentation strategies, we measured attributions across a large and diverse set of traits (the 18 traits listed in table 1) and for each set asked respondents to partition the influence of three potential causes-

Table 1. Attribution of 18 Traits to Genetics, the Environment, and Personal Choice (\%)

\begin{tabular}{|c|c|c|c|}
\hline \multirow[b]{2}{*}{ Trait } & \multicolumn{3}{|c|}{ Mean Attribution To: } \\
\hline & Genetics & $\begin{array}{c}\text { Environmental } \\
\text { Factors }\end{array}$ & $\begin{array}{c}\text { Personal } \\
\text { Choice }\end{array}$ \\
\hline Height & 88.52 & 6.48 & 5.00 \\
\hline Mentally disabled & 80.33 & 13.01 & 6.66 \\
\hline Handedness & 73.73 & 10.51 & 15.77 \\
\hline Intelligence & 56.12 & 20.39 & 23.50 \\
\hline Being homosexual & 50.94 & 15.71 & 33.36 \\
\hline Athletic ability & 50.68 & 16.33 & 32.99 \\
\hline Obese & 41.77 & 21.82 & 36.41 \\
\hline Anxious or neurotic & 37.48 & 36.42 & 26.11 \\
\hline Extroverted & 35.67 & 32.75 & 31.58 \\
\hline Aptitude for language & 35.13 & 28.32 & 36.55 \\
\hline Eating disorder & 23.70 & 37.66 & 38.64 \\
\hline Conscientiousness & 23.56 & 29.32 & 47.12 \\
\hline Addicted to drugs & 20.62 & 32.32 & 47.06 \\
\hline $\begin{array}{l}\text { Open to new } \\
\text { experiences }\end{array}$ & 17.69 & 31.77 & 50.54 \\
\hline $\begin{array}{l}\text { Tolerant of } \\
\text { differences }\end{array}$ & 11.12 & 36.36 & 52.52 \\
\hline Criminal record & 11.09 & 33.94 & 54.97 \\
\hline Political ideology & 8.56 & 37.30 & 54.14 \\
\hline Deeply religious & 8.42 & 38.78 & 52.80 \\
\hline
\end{tabular}

Note. $N=600$. genetics, the environment, and personal choice-so that these influences summed to $100 \%$. For example, if people believe drug addiction to be primarily the result of autonomous personal choice and only slightly attributable to genetics and to the environment, they might attribute $70 \%$ to personal choice, $15 \%$ to genetics, and $15 \%$ to environmental causes. These items on attributions along with additional items on political orientation, demographics, tolerance, and racial attitudes were then included in two specially commissioned surveys administered to nationally representative samples by YouGov (see the appendix, available online, for sampling details and all item wordings). The first survey ( $N=600$; fielded in the spring of 2015) focused on the degree to which attributions covaried with tolerance, and the second ( $N=600$; fielded in the late summer of 2015) concentrated on the connection to trait attributions and attitudes concerning race.

In table 1, we present people's attributions for the 18 traits included in the first survey. This descriptive information is interesting and important in its own right. Perceptions of the role of genetics vary widely depending on the trait. At the top end, people believe that height and mental disabilities are shaped primarily by genetics, with only a small role remaining for the environment and personal choice. At the bottom end, people believe that genetics plays very little role (under 10\%) in shaping people's political and religious views. Aptitudes and personality traits are arrayed in between these extremes. The wisdom of including personal choice as a distinct option is apparent in the table. In fact, averaging across all traits, people are more likely to see personal choice than environmental factors as a source of trait variance.

We now turn to our core objective, which is to ascertain whether individuals who tend to attribute a large role to genetics are more (or less) likely to be politically conservative, intolerant, and racially prejudiced. Since our data are correlational, they do not indicate whether attributional tendencies affect ideology, tolerance, and racism, or the other way around. Fortunately, sorting out the causal order is not necessary because we are only interested in the degree to which genetic attributions are accompanied by particular political and social attitudes. Given uncertainty about the causal order, instead of using regression analysis, we calculated partial correlations between genetic attributions and the concepts of interest while controlling for the usual variables: age, income, education, race $($ white $=1$, nonwhite $=0)$, sex (female $=1$, male $=0$ ), and frequency of church attendance. Our primary measure of ideology was YouGov's standard five-point item ranging from $1=$ strong liberal to $5=$ strong conservative (alternatives to this measure are analyzed in the appendix). Our main variable (the degree to which each respondent attributed traits to genetics) was calculated by averaging each 
respondent's attribution to genetics across all 18 traits in table 1.

The results are presented in table 2. The demographic variables suggest that older, less educated, churchgoing individuals are more likely to be conservative, as might have been expected, but the more relevant finding is that after controlling for these variables, there is a negative correlation between conservatism and the tendency to attribute a wide variety of traits to genetic causes. In other words, contrary to conventional wisdom, self-reported liberals are actually more likely than conservatives to attribute trait variation to genetics; these results hold if, instead of looking at global attributional tendencies, we run separate models for each of the 18 traits (see the appendix). When this is done, we find that for none of the 18 traits are genetic attributions significantly related to being conservative, and for 4 of the 18 traits there is a significant relationship with being liberal.

What about tolerance? Are those who attribute variation in traits to genetics less likely to be tolerant of diversity, as conventional wisdom anticipates? In compiling our first survey instrument, we singled out 5 of the 18 traits in table 1 for additional items on tolerance: homosexuality, drug addiction, obesity, mental disabilities, and political ideology. We tapped respondents' openness to and tolerance of individuals with each of these traits, using items common in the tolerance literature (Schnittker 2000). We created models similar to those presented in table 2, except that we now include three additional variables. One is labeled "trait used to describe"; it is a dummy variable that captures whether the respondent reported that he or she had "a family member or close friend" who has been described as having that particular trait. Another is a control for ideological self-placement (described above), and the third is party identification ( $7=$ strong Republican; $1=$ strong Democrat). In addition, for the five tolerance models, the variable labeled "genetic attribution" changes from mean attributions across all 18 variables to attributions for the particular trait (homosexuals, drug addicts, obese people, etc.) that is being tolerated-or not.

With other variables controlled, the tendency to attribute the source of a trait to genetics correlates positively with tolerance of homosexuals, drug addicts, the obese, and the mentally disabled $(p<.01)$. The only exception to the pattern is tolerance of those with opposing political beliefs (see also Suhay and Jayaratne 2013), and this finding should be taken with a grain of salt since the relationship appears to be driven by distorted variance (two-thirds assigned $0 \%$ of political beliefs to genetics, and a small number of outliers assigned $100 \%)$.

Our first survey did not include items on race, so we conducted a second survey a few months later. To measure genetic trait attributions, we included 12 of the 18 attributional items from table 1 (height, obesity, eating disorders, anxiety, openness, and religiosity were excluded to make room for the additional racial items). We focus on just two racial groups here: whites and African Americans. The survey contained items designed to tap five aspects of racial

Table 2. Partial Correlations for Ideology, Tolerance, and Genetic Attributions

Tolerance Toward:

\begin{tabular}{|c|c|c|c|c|c|c|}
\hline Variable & $\begin{array}{l}\text { Conservative } \\
\text { Ideology }\end{array}$ & Homosexuals & Drug Addicts & $\begin{array}{l}\text { Obese } \\
\text { People }\end{array}$ & $\begin{array}{l}\text { Mentally } \\
\text { Disabled }\end{array}$ & $\begin{array}{c}\text { People with Opposite } \\
\text { Ideology }\end{array}$ \\
\hline Genetic attribution & $-.208^{\star *}$ & $.370^{\star *}$ & $.172^{\star *}$ & $.147^{\star *}$ & $.248^{\star *}$ & $-.106^{\star *}$ \\
\hline Female & -.033 & $.113^{*}$ & .044 & .059 & $.116^{*}$ & -.041 \\
\hline Age & $.206^{\star *}$ & -.089 & $-.177^{\star \star}$ & -.045 & $-.143^{\star \star}$ & -.055 \\
\hline White & .073 & -.017 & $.159^{\star *}$ & .070 & $.105^{\star}$ & .049 \\
\hline Religious attendance & $.332^{\star *}$ & $-.127^{\star *}$ & $.117^{\star}$ & -.053 & .092 & .010 \\
\hline Education & $-.099^{*}$ & $.122^{\star \star}$ & .053 & $.123^{\star \star}$ & .030 & $.099^{\star *}$ \\
\hline Income & .047 & .025 & -.011 & -.019 & -.060 & .016 \\
\hline Conservative (ideology) & & $-.164^{\star *}$ & $-.152^{\star \star}$ & -.083 & $-.122^{\star \star}$ & $-.099^{\star *}$ \\
\hline Republican (partisanship) & & .058 & $-.105^{\star}$ & -.022 & -.079 & -.037 \\
\hline Trait used to describe & & $.197^{\star \star}$ & $.160^{\star *}$ & $.219^{* *}$ & .057 & .026 \\
\hline
\end{tabular}

Note. For conservative ideology, we include the respondents' average attribution to genetics for all 18 traits. For the five tolerance measures, we include the respondents' attribution to genetics for that particular trait. $N=458$.

${ }^{*} p<.05$.

${ }^{* *} p<.01$. 
Table 3. Partial Correlations for Racial Attitudes and Genetic Attributions

\begin{tabular}{|c|c|c|c|c|c|}
\hline Variable & Symbolic Racism & Affirmative Action & Racial Tolerance & Racial Differences & Black Homogeneity \\
\hline Genetic attributions & $-.119^{*}$ & .054 & $-.101^{*}$ & -.025 & .002 \\
\hline Female & .001 & .029 & .055 & -.079 & .033 \\
\hline Age & .078 & -.007 & -.028 & -.051 & $-.097^{\star}$ \\
\hline White & .016 & $-.175^{\star \star}$ & .086 & -.061 & $.104^{\star}$ \\
\hline Religious attendance & -.058 & $.121^{\star}$ & .025 & -.020 & -.078 \\
\hline Education & .003 & -.041 & $.099^{*}$ & $-.130^{\star *}$ & .045 \\
\hline Income & .002 & -.026 & $.109^{*}$ & .077 & -.021 \\
\hline Conservative (ideology) & $.319^{\star *}$ & $-.275^{\star *}$ & -.093 & $.158^{\star \star}$ & .054 \\
\hline Republican (partisanship) & $.219^{\star *}$ & $-.199^{\star *}$ & -.082 & -.006 & .047 \\
\hline
\end{tabular}

Note. $N=437$.

${ }^{*} p<.05$.

${ }^{* *} p<.01$.

attitudes. The first three were the six-item measure of "symbolic racism" (sometimes referred to as racial resentment), a two-item indicator of support for race-based affirmative action, and a four-item indicator of racial tolerance structurally similar to the tolerance measures used in table 2. We also included a measure of the extent to which people rated African Americans and whites differently on scales of intelligence, athletic ability, criminal tendencies, and conscientiousness, as well as a measure of the extent to which African Americans are perceived as being more homogeneous than whites (another indicator of racial biases).

We calculated the partial correlation coefficients for each of these five measures of racial attitudes in models parallel to those employed in table 2, and the results are presented in table 3. Coefficients for the control variables are not particularly surprising. For four of the five racial variables, however, the results are inconsistent with the expectation that genetic attributions are associated with unenlightened racial attitudes. The coefficients for affirmative action, perception of racial differences, and differences in perception of group homogeneity are statistically insignificant, and the coefficient for symbolic racism actually suggests that those making genetic attributions are significantly less likely to be racist. Even the one instance in which genetic attributions seem to be associated with racially unfavorable attitudes - racial tolerance - is questionable since it drops below statistical significance when the analysis is repeated with only white respondents (see the appendix). Regardless, the overall picture in table 3 is at odds with the widespread belief that attributing variation in individual behaviors to genetics correlates with repugnant racial perceptions and attitudes, appearing instead to have little overall effect.

In sum, we find that a key assumption underlying prevailing intellectual dogma - that compassionate, tolerant, ra- cially enlightened individuals tend to deny that genetics is relevant to human variation - is factually inaccurate. Rather, people who accord genetics a role in explaining the different traits that humans possess are significantly more likely to be politically liberal; significantly more likely to be tolerant of homosexuals, drug addicts, the obese, and those with mental disabilities; and no more likely to hold unenlightened racial attitudes. Instead, those who believe traits are under personal control are the ones who tend to hold less tolerant attitudes.

\section{ACKNOWLEDGMENTS}

We would like to thank the Political Behavior Reading Group in the Department of Political Science at the University of Nebraska-Lincoln for helpful comments. We also thank our anonymous reviewers for their feedback. This research was approved by the University of Nebraska-Lincoln, Institutional Review Board.

\section{REFERENCES}

Condit, Celeste M., Roxanne L. Parrott, and Tina Harris. 2006. "Laypeople and Behavioral Genetics.” In Erik Parens, Audrey R. Chapman, and Nancy Press, eds., Wrestling with Behavioral Genetics. Baltimore: Johns Hopkins University Press, 286-309.

Gould, Stephen Jay. 1996. The Mismeasure of Man. New York: Norton.

Haider-Markel, Donald P., and Mark R. Joslyn. 2008. "Beliefs about the Origins of Homosexuality and Support for Gay Rights.” Public Opinion Quarterly 72 (2): 291-310.

Heine, Steven J., Ilan Dar-Nimrod, Benjamin Y. Cheung, and Travis Proulx. 2017. "Essentially Biased: Why People Are Fatalistic about Genes." Advances in Experimental Social Psychology 55:137-92.

Joslyn, Mark R., and Donald P. Haider-Markel. 2016. "Genetic Attributions, Immutability, and Stereotypical Judgments.” Social Science Quarterly 97 (2): 376-90.

Lewontin, Richard C., Steven Rose, and Leon Kamin. 1984. Not in Our Genes: Biology, Ideology, and Human Nature. New York: Pantheon. 
Schnittker, Jason. 2000. "Gender and Reactions to Psychological Problems: An Examination of Social Tolerance and Perceived Dangerousness." Lournal of Health and Social Behavior 41 (2): 224-40.

Shostak, Sara, Jeremy Freese, Bruce G. Link, and Jo C. Phelan. 2009. "The Politics of the Gene." Social Psychology Quarterly 72 (1): 77-93.
Suhay, Elizabeth, and Toby Epstein Jayaratne. 2013. "Does Biology Justify Ideology? The Politics of Genetic Attribution.” Public Opinion Quarterly 77 (2): 497-521.

Weiner, Bernard. 1985. "An Attributional Theory of Achievement, Motivation, and Emotion.” Psychological Review 92 (4): 548-73.

This content downloaded from 129.093.168.010 on November 05, 2018 09:27:59 AM 